\title{
A Review of Methods Applied to Study Airborne Biocontaminants inside Aircraft Cabins
}

\author{
Sandro Tavares Conceição, ${ }^{1}$ Marcelo Luiz Pereira, ${ }^{2}$ and Arlindo Tribess ${ }^{3}$ \\ ${ }^{1}$ Postgraduate Program in Mechanical Engineering, Polytechnic School, (USP) University of São Paulo, 12244-396 São José dos Campos, \\ (SP), Brazil \\ ${ }^{2}$ Science and Technology of Santa Catarina, (IFSC) Federal Institute of Education, 88103-902 São José, (SC), Brazil \\ ${ }^{3}$ Department of Mechanical Engineering, Polytechnic School, (USP) University of São Paulo, 05508-900 São Paulo, (SP), Brazil
}

Correspondence should be addressed to Sandro Tavares Conceição, satavaco@usp.br

Received 31 March 2011; Accepted 4 June 2011

Academic Editor: Keh-Chin Chang

Copyright (C) 2011 Sandro Tavares Conceição et al. This is an open access article distributed under the Creative Commons Attribution License, which permits unrestricted use, distribution, and reproduction in any medium, provided the original work is properly cited.

\begin{abstract}
Indoor-cross infection of expiratory contaminants is still a concern, worsened by the SARS outbreak in 2003 and recent cases of influenza strains ( $\mathrm{H} 1 \mathrm{~N} 1$, avian flu, etc.). A variety of methods to study the airborne spread of expiratory contaminants have been worked out, including the use of tracer gas, particle generators, and CFD simulations. In this context, the main objective of this work is reviewing methods to evaluate airborne dispersion of contaminants, more specifically those related to cross infection of expiratory droplets inside aircraft cabins. This literature review provides guidance in developing methods and choosing equipment for future studies. This study gathers knowledge developed so far in a common source, serving as a guideline for researchers who work in this area.
\end{abstract}

\section{Introduction}

Approximately 3.2 billion passengers have travelled in the world in 2006 [1], and a significant part of them have said they are worried about germs when flying [2]. Although the aircraft manufactures have made advances in cabin safety, and the airlines have undertaken different actions to minimize the threat of inflight transmission of diseases, the risk of airborne cross infection indeed cannot be eliminated entirely, as discussed by Fishbein et al. [3]. Various recent studies supports that concern, such as the one made in 2003, showing that the virus SARS has been fast disseminated throughout the world, mainly because infected people have traveled by aircraft between distant cities [4]. Mangili and Gendreau [5] have discussed many cases of spread of infectious diseases inside aircraft cabins. More recently, Wagner et al. [6] have calculated the potential transmission by an H1N1-infected person in the economy class of an air-liner and predicted 2 to 5 infections for a 5 hour flight and up to 17 for a 17 hour flight.
Although there are several cases in the literature, one believes that the transmission of infectious diseases originated from cross infection inside aircraft cabins happen more than registered [7], what could be explained by the incubation time of some infections, which may be larger than the flight duration. In this case, although some passengers could have been infected during the flight, the symptoms would appear in a few days or so afterwards, and it would be difficult to assure if the illnesses were really contracted inside the aircraft. In addition, passengers can be in the asymptomatic period of an illness and boarding an aircraft without attracting others attention [5].

Some intrinsic characteristics of the current aircraft air conditioning system may be favorable for airborne cross infection, mainly during long flights when the exposure time is longer. For instance, the use of mixing ventilation might potentially increase the spread of contaminants inside cabins due to its mixing effect $[8,9]$. The HEPA filters present in aircraft [10-12] are effective in removing virus and bacteria, but are usually installed in the recirculation air 
ducts only. Thus, the contaminants generated by the index passenger can be inhaled by other occupants before being collected by those filters. Sze To et al. [13], for instance, have experimentally observed that the expiratory droplets generated by a simulated coughing have reached the entire 21 seats aircraft cabin mockup in 20 seconds, even considering $100 \%$ of fresh air flow in the experiments.

Many researchers have focused on understanding the correlation between the type of ventilation system with the transmission of airborne infectious diseases [14-17]. Some studies compare the application of mixing ventilation with underfloor air and personalized ventilation (PV) specifically inside aircraft cabin $[9,18]$, but there is a lack of validation data on those studies.

In order to evaluate the spread of airborne contaminants inside aircraft cabins, distinct methods have been applied to reproduce pollutant generation, such as tracer gas and particle generators. Additionally, several measurement techniques are required to characterize the particles. In order to simulate particle dynamics, many researchers have been using Computational Fluid Dynamics (CFD) $[19,20]$.

The methods applied to reproduce the dynamic of airborne droplets are fundamental to fully understand its behaviour and also to comprehend the influence of the ventilation system on it. In this direction, the main objective of this work is reviewing the methods applied to evaluate the spread of airborne contaminants inside aircraft cabins, focusing on cross-infection caused by expiratory activities and to initiate a discussion of a method to be applied to evaluate ventilation systems in terms of indoor air quality.

\section{The Literature Review}

The literature review has focused on indoor airborne transport of particles, more specifically, those studies related to cross infection of airborne expiratory droplets inside aircraft cabins. Some studies done in buildings are also cited, because it is assumed that the methods applied to building interiors, a priori, can be applied to the aircraft cabin as well.

As the present work deals with the dispersion of contaminant inside aircraft cabins, it is important to discuss some basic aspects of cabin ventilation philosophies. Afterwards, some characteristics of the biocontaminants of interest are presented, since they are protagonist of the cross infection cases inside aircraft cabins. Finally, studies related to airborne spread of biocontaminants inside aircraft cabins are presented, including experimental and numerical aspects.

2.1. Overview of Aircraft Ventilation Systems. The air distribution system is one of the main components of the Environmental Control System (ECS), responsible for adequately distributing the conditioned air aiming at bringing the occupants health and thermal comfort. Aircraft cabins have a higher occupant density, a more complex internal geometry, smaller volume, and a smaller fresh air flow per occupant if compared to buildings (Figure 1).

Mainly due to its smaller air volume and a much higher occupant density [21], the total cabin air exchange ratio is

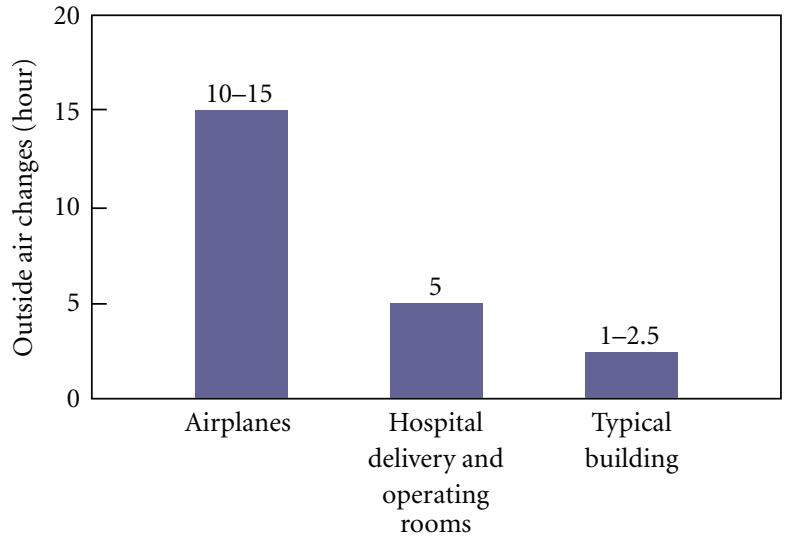

FIGURE 1: Outside air changes per hour in different environments $[10]$.

TABle 1: Typical values for people density and total air exchange rates $[21]$.

\begin{tabular}{lcc}
\hline & Buildings & Aircraft cabins \\
\hline People density & 7 occupants $/ 283 \mathrm{~m}^{3}$ & 230 occupants $/ 283 \mathrm{~m}^{3}$ \\
\hline $\begin{array}{l}\text { Total air exchange } \\
\text { rate (outdoor }+\end{array}$ & $50 \mathrm{~L} / \mathrm{s} /$ person \\
recirculated air) & $(100 \mathrm{CFM} /$ person $)$ & $\begin{array}{c}7.5 \text { to } 10 \mathrm{~L} / \mathrm{s} / \text { person } \\
(15 \text { to } 20 \mathrm{CFM} / \text { person })\end{array}$ \\
\hline
\end{tabular}

much higher than that in buildings (Table 1). Therefore, it is usually more challenge to design a healthy and comfort environment inside aircraft cabins.

The cabin ventilation is usually done with airflow at elevated velocity entering the overhead region, with the air return next to the floor (Figure 2) resulting in the air mixture through the cabin volume and, therefore, named "mixing ventilation"-MV. It typically produces minor air temperature stratification but, due to its mixing effect, it can potentially increase the spread of infectious diseases through the cabin $[8,9]$.

Displacement ventilation-DV [22] and underfloor air distribution-UFAD $[23,24]$ have been studied and already applied in buildings. This ventilation type might be able to improve the air quality around the occupant breathing zone if compared with mixing ventilation [25] but, on the other hand, can increase the local thermal discomfort by draft [15, 26]. This negative effect could be worsen in aircraft cabins where the volume of air per passenger and the ceiling height are much smaller than those in buildings.

The application of Personalized Ventilation (PV) has been recently studied in buildings [14, 24, 27, 28]. The PVs main objective is to bring passengers individual thermal control and to minimize the entrance of contaminants in the occupant breathing zone $[29,30]$. Although this philosophy has being applied with success in buildings $[14,31,32]$, they have not being effectively applied in aircraft cabins. The only exception is the personal airflow outlet usually present in aircraft cabins, known by gasper valves, which might not be so effective to promote to each passenger his individual thermal control [33]. Finally, some conceptual ideas of PV 


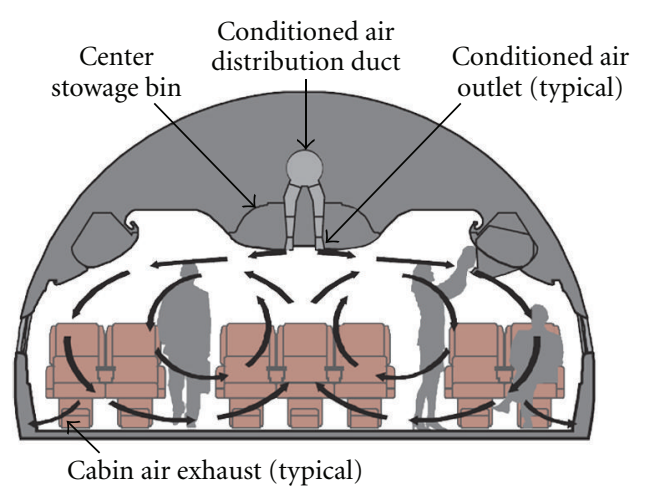

Figure 2: A typical mixing ventilation system [10].

for aircraft cabin have being investigated with CFD studies $[9,18]$, showing benefits in terms of thermal comfort and air quality compared with the traditional mixing ventilation. However, there is a lack of validation data on those studies.

Although the design of the aircraft cabin ventilation is a challenge, it might be possible to enhance it in order to guarantee better air quality in the occupants' breathing zone without jeopardizing thermal comfort and then contributing to minimize the risk of inflight cross infection. The use of PV combined with other types of ventilation seems to be a possible solution. So, in order to comprehend the influence of the different ventilation systems on the dispersion of biocontaminants, it is fundamental reviewing the state of the art of the methods applied to reproduce the dynamic of airborne droplets inside aircraft cabins, what is done in the next items.

2.2. Expiratory Contaminants. During expiratory activities such as coughing, talking, and sneezing, humans atomise droplets. If these droplets are produced by an infected person, pathogenic contaminants present at his expiratory tract are carried outside and can be directly transmitted to other people via inhalation, one of the central causes of crossinfection. As per Duguid [34], approximately $95 \%$ of the expiratory droplets have a size between 2 and $100 \mu \mathrm{m}$, being the most common particles between 4 and $8 \mu \mathrm{m}$ (Figure 3 ). Although sneezing produces more particles, coughing occurs more often and, in the end, becomes the most particlegenerating activity [35].

In general, particles larger than $5 \mu \mathrm{m}$ deposit on surfaces quickly, mainly due to the force of gravity [7]. The smaller particles-instead, have a diffusion coefficient in the air comparable to the diffusion coefficient of gases [36], which allows them to be carried by the airflow enough to evaporate and form its residue called droplet nuclei. As a result, these residues are able to transport contaminants for longer distances [37]. Although the smaller aerosols follow the airflow as if they were gaseous particles, they usually adhere to the surface of an obstacle after hitting it, whereas the gaseous usually rebound [36].

According to Yang et al. [16], the droplets concentration released per coughing is around $10^{9} / \mathrm{m}^{3}$. Based on Duguid, 1946 measurements, it is possible to infer that the quantity of particles produced by sneezing is around 200 times the quantity produced during coughing. Considering that the concentration would increase in the same proportion, it is possible to assume that a sneezing concentration has the order of $10^{11} / \mathrm{m}^{3}$. On the other hand, recent study [38] consider that the droplets concentration produced by coughing is around $2.4 \cdot 10^{6} / \mathrm{m}^{3}$ to $5.2 \cdot 10^{6} / \mathrm{m}^{3}$, which is around three orders of magnitude lower than the numbers from Yang et al. [16].

Based on the last paragraph, it is possible to notice controversial values in some studies characterizing expiratory contaminants, what might be explained in part by the difficulties associated to the measuring methods [38]. Table 2 summarizes the discussed and some others studies $[39,40]$ found in the literature review related to expiratorycontaminant quantities.

2.3. Tracer Gas Studies. Nielsen [15] evaluated the performance of two types of PV systems applied in aircraft cabins: one integrated to a neck-support pillow, and the other integrated to the seat, as shown in Figure 4. The authors have used $\mathrm{N}_{2} \mathrm{O}$ as tracer gas and smoke to evaluate qualitatively the PVs jet entrainment in the person's breathing zone. The PV response for larger droplets has not been evaluated. As the testing solutions were not inserted in an aircraft environment, they did not capture the interactions between the PV and the aircraft global ventilation, as well the influence of other interior obstacles, such as the occupants' bodies and the seats located at adjacent rows. The authors have concluded that the PV integrated to the neck pillow is more efficient to avoid cross infection than the PV integrated to the seat.

Yan et al. [20] have studied the airborne pollutant transport mechanism inside aircraft cabins using tracer gas (Figure 5). $7.5 \cdot 10^{-5} \mathrm{~m}^{3} / \mathrm{s}$ of $\mathrm{CO}_{2}$ was injected into the cabin from the mouth of a simulated infected passenger during 5 minutes. The gas concentrations at the breathing region of the other occupants were measured with fourteen nondispersive infrared sensors, considering a sampling rate of $0.5 \mathrm{~Hz}$. Due to the sensors' limited number, two rows were measured each time. They have applied Volumetric Particle-Tracking Velocimetry (VPVT) to measure airflow velocity's field and have considered box-shaped mannequin without thermal dissipation to simplify experiments. CFD simulations were applied to model $\mathrm{CO}_{2}$ concentration along the cabin in an Eulerian frame, and the airflow was modelled with $\mathrm{k}-\varepsilon$ standard turbulence model, although some researchers have concluded that the RNG model is usually better for this kind of application $[45,46]$.

The authors have made mesh refinement around the mannequins due to their geometry complexity and the expected high-velocity gradients. Coarser mesh was considered for the rest of the cabin, totalizing around 1.6 million volumes. Good numerical-experimental correlations for the temperature field were obtained, but not so good for the velocities, what could be explained by the simplifications done to the geometry of the virtual mannequins. The simulated contaminant concentration field was quite different from the measured one. One reason to explain the differences 
TABLE 2: Expiratory droplet characteristics.

\begin{tabular}{|c|c|c|c|c|c|c|c|}
\hline Reference & Type & $\begin{array}{l}\text { Expiratory } \\
\text { activity }\end{array}$ & Gas/aerosol & Quantity & $\begin{array}{c}\text { Concentration } \\
\left(\# / \mathrm{m}^{3}\right)\end{array}$ & Size $\left(10^{-6} \mathrm{~m}\right)$ & $\begin{array}{c}\text { Velocity } \\
(\mathrm{m} / \mathrm{s})\end{array}$ \\
\hline Zhang and Chen [9] & Num & $\begin{array}{c}\text { Human } \\
\text { breathing }\end{array}$ & $\mathrm{CO}_{2}$ & $5 \cdot 10^{-6} \mathrm{~m}^{3} / \mathrm{s}$ & N/A & N/A & $?$ \\
\hline Yang et al. [16] & Exp & Coughing & $\begin{array}{c}\text { Human subject, } \\
\text { polydispersed }\end{array}$ & $9 \cdot 10^{-4} \mathrm{~m}^{3} / \mathrm{s}(\max )$ & $2.4 \cdot 10^{9}(\max )$ & $\begin{array}{c}\text { Peaks at } 1,4, \\
\text { and } 8\end{array}$ & $?$ \\
\hline Gao and Niu [18] & Num & Sneezing & $\begin{array}{c}\text { Water, } \\
\text { monodispersed } \\
\end{array}$ & 9600/sneezing & $?$ & 1 & 20 \\
\hline \multirow[t]{2}{*}{ Yan et al. [20] } & $\begin{array}{l}\text { Num and } \\
\text { Exp }\end{array}$ & $\begin{array}{l}\text { Not specified } \\
\text { (general) }\end{array}$ & $\mathrm{CO}_{2}$ & $7.5 \cdot 10^{-5} \mathrm{~m}^{3} / \mathrm{s}$ & N/A & N/A & $?$ \\
\hline & & $\begin{array}{c}\text { Speaking } \\
\text { (counting } \\
1-100)\end{array}$ & $\begin{array}{l}\text { Human subject, } \\
\text { polydispersed }\end{array}$ & 250/speaking & $?$ & & $?$ \\
\hline \multirow[t]{2}{*}{ Duguid [34] } & Exp & Coughing & $\begin{array}{c}\text { Human subject, } \\
\text { polydispersed }\end{array}$ & 5.000/coughing & $?$ & $\begin{array}{l}4-8 \text { (most } \\
\text { common) }\end{array}$ & $?$ \\
\hline & & Sneezing & $\begin{array}{c}\text { Human subject, } \\
\text { polydispersed }\end{array}$ & $1.000 .000 /$ sneezing & $?$ & & $?$ \\
\hline \multirow[t]{2}{*}{ Chao et al. [38] } & \multirow[t]{2}{*}{ Exp } & Coughing & $\begin{array}{l}\text { Human subject, } \\
\text { polydispersed }\end{array}$ & $\begin{array}{c}2085 \\
(\max ) / \text { coughing }\end{array}$ & $5.2 \cdot 10^{6}(\max )$ & $4-8$ & 11.7 \\
\hline & & $\begin{array}{c}\text { Speaking } \\
\text { (counting } \\
\text { from 1-100) }\end{array}$ & $\begin{array}{l}\text { Human subject, } \\
\text { polydispersed }\end{array}$ & $\begin{array}{c}6720 \\
(\max ) / \text { speaking }\end{array}$ & $2.2 \cdot 10^{5}(\max )$ & $\begin{array}{l}4-8 \text { (most } \\
\text { common) }\end{array}$ & 3.1 \\
\hline Fabian et al. [39] & Exp & Breathing & $\begin{array}{c}\text { Human subject, } \\
\text { polydispersed }\end{array}$ & $?$ & $8.4 \cdot 10^{6}(\max )$ & $0.3-0.5$ & $?$ \\
\hline $\begin{array}{l}\text { Fairchild and } \\
\text { Stampfer [40] }\end{array}$ & Exp & Breathing & $\begin{array}{c}\text { Human subject, } \\
\text { polydispersed }\end{array}$ & $?$ & $9.9 \cdot 10^{5}$ & $?$ & $?$ \\
\hline Wan et al. [41] & $\begin{array}{l}\text { Num and } \\
\text { Exp }\end{array}$ & Coughing & $\begin{array}{c}\text { Water, } \\
\text { polydispersed }\end{array}$ & $?$ & $2.5 \cdot 10^{9}$ & $\begin{array}{c}6.75 \\
\text { (medium) } \\
\end{array}$ & 10 \\
\hline \multirow[t]{2}{*}{ Zhang et al. [42] } & \multirow{2}{*}{$\begin{array}{l}\text { Num and } \\
\text { Exp }\end{array}$} & \multirow{2}{*}{$\begin{array}{l}\text { Not specified } \\
\quad \text { (general) }\end{array}$} & $\begin{array}{c}\text { DEHS, } \\
\text { monodispersed }\end{array}$ & $7.5 \cdot 10^{-5} \mathrm{~m}^{3} / \mathrm{s}$ & $10^{12}$ & 0.7 & $?$ \\
\hline & & & $\mathrm{SF}_{6}$ & $5 \cdot 10^{-8} \mathrm{~m}^{3} / \mathrm{s}$ & $\mathrm{N} / \mathrm{A}$ & N/A & $?$ \\
\hline \multirow[t]{2}{*}{ Shimada et al. [43] } & $\begin{array}{l}\text { Num and } \\
\text { Exp }\end{array}$ & $\begin{array}{l}\text { Not specified } \\
\text { (general) }\end{array}$ & $\begin{array}{c}\text { latex polystyrene, } \\
\text { polydispersed }\end{array}$ & $1.7 \cdot 10^{-5} \mathrm{~m}^{3} / \mathrm{s}$ & $3 \cdot 10^{10}$ & 0.14 & $?$ \\
\hline & & Coughing & $\begin{array}{c}\text { Water, } \\
\text { monodispersed }\end{array}$ & $10^{6} /$ coughing & $?$ & 8.5 & $9(\max )$ \\
\hline \multirow[t]{3}{*}{ Gupta et al. [44] } & $\begin{array}{l}\text { Num and } \\
\text { Exp }\end{array}$ & Breath & $\begin{array}{c}\text { Water, } \\
\text { monodispersed }\end{array}$ & 525/breathing & $?$ & 0.4 & $4(\max )$ \\
\hline & & $\begin{array}{l}\text { Talking (for } 15 \\
\text { second talk) }\end{array}$ & $\begin{array}{c}\text { Water, } \\
\text { monodispersed }\end{array}$ & 2250/talking & $?$ & 30 & $?$ \\
\hline & & Talking & & $?$ & $9.9 \cdot 10^{5}$ & $?$ & $?$ \\
\hline
\end{tabular}

Num: numerical; Exp: experimental; ?: not informed; N/A: not applicable; max: maximum.

is the low number of measuring points, what forced them to calculate concentration in nonmeasured regions with numerical interpolation. In general, they have concluded that the ventilation system influences considerably on the concentration map inside the cabin and have obtained lower contaminant concentration for higher ventilation ratios.

Zhang and Chen [9] have applied CFD to simulate the dispersion of $\mathrm{CO}_{2}$ generated by passengers inside aircraft cabin considering three different kinds of ventilation: mixture ventilation, underfloor ventilation, and underfloor ventilation combined with PV (Figure 6). It was considered adiabatic seats, box-type mannequin with thermal dissipation, and periodicity boundary condition applied on both cabin edges. The cabin was divided in 24 subvolumes to make the grid generation easier, and hexahedral volumes were considered around the occupants. The grid size was around $5 \mathrm{~cm}$, what is considered adequate by the authors since they wanted to study the global airflow, instead of the detailed airflow around the passengers. They have applied $\mathrm{CO}_{2}$ as tracer gas, which was continuously injected at a rate of $5 \cdot 10^{-6} \mathrm{~m}^{3} / \mathrm{s}$ per passenger, and its concentration modeled with Euler models. The authors have concluded that the PV 


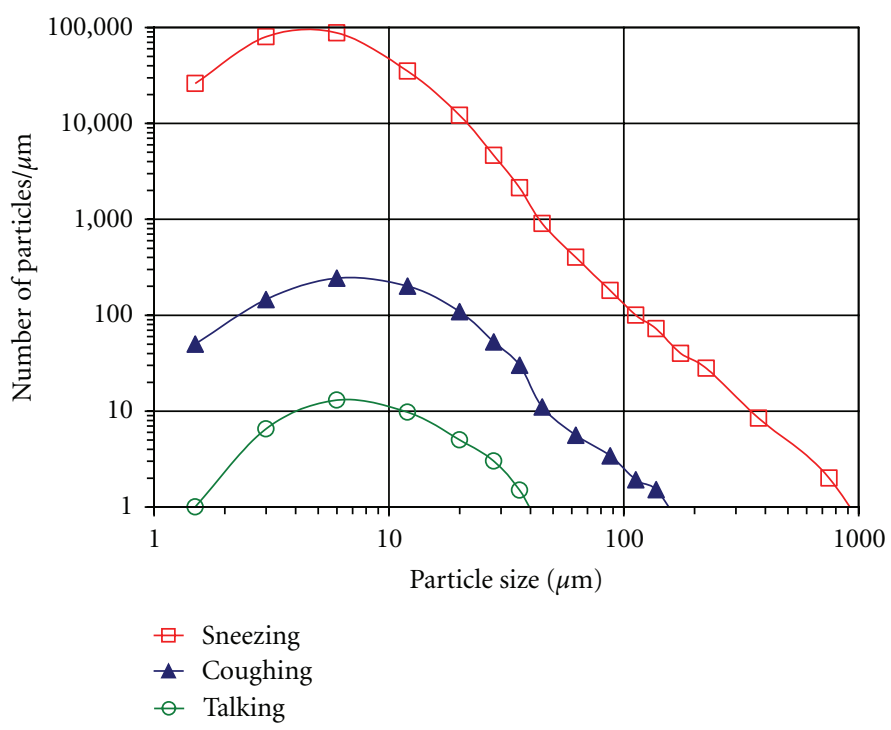

\begin{tabular}{|l|c|}
\hline Expiratory activity & Number of particles \\
\hline 1 sneezing & $1,000,000$ \\
\hline 1 coughing with mouth closed & 5,000 \\
\hline Counting loudly "1"-“100" & 250 \\
\hline
\end{tabular}

FIGURE 3: Number of particles normalized for interval width produced by human expiratory activities as a function of particle size-based on data from Duguid [34].

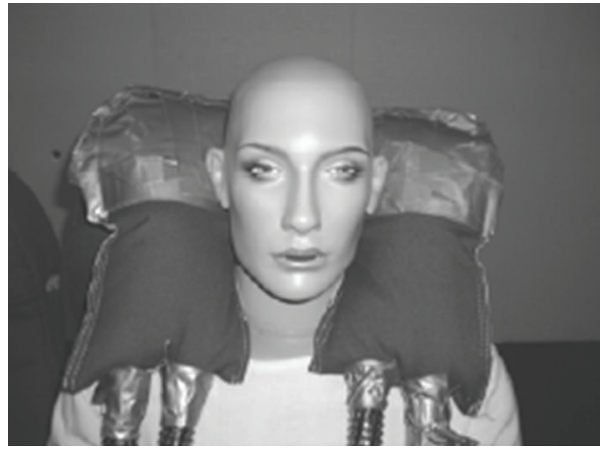

(a)

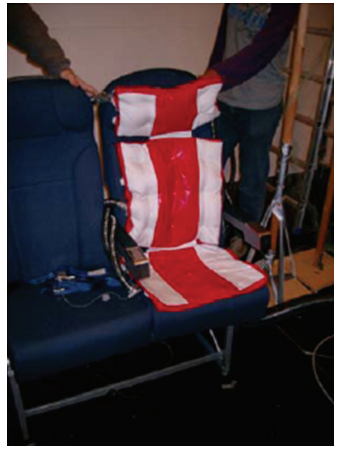

(b)

FIGURE 4: PVs integrated to aircraft seats to study cross infection. (a) PV integrated to the neck-support pillow, (b) PV integrated to the seat [15].

combined with UFAD system has improved the air quality of the passengers compared to mixing ventilation but have not shown experimental validation for this specific investigation.

Similar study was developed by Gao and Niu [18] to evaluate PV integrated to the aircraft cabin seat armrest (Figure 7) combined with mixing ventilation, compared to a pure mixing ventilation system, keeping the same fresh airflow rate for both configurations. A thermal mannequin scanned from a real detailed mannequin was considered in the simulation and the pollutant emitted from the floor and from the occupant skin and nose. A constant inhalation rate of $1.4 \cdot 10^{-4} \mathrm{~m}^{3} / \mathrm{s}$ was considered for all the passengers, except for the index one. The gaseous contaminant dispersion was simulated by injecting $\mathrm{CO}_{2}$ in an Eulerean frame, and the aerosol dispersion simulated with both the Eulerean and Lagrangean models.

First, the airflow was solved considering RNG k- $\varepsilon$ turbulence models with standard wall functions. Then, disperse phase equations were solved, assuming one-way coupling. The dispersed aerosols were considered spherical particles with medium diameter of $1 \mu \mathrm{m}$ and simulated in a Lagrangean frame of reference. These particles were injected 


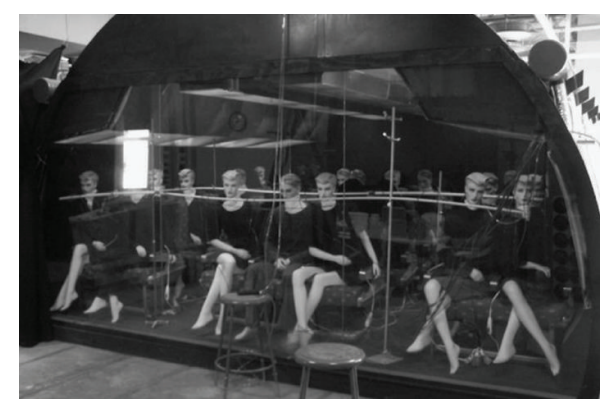

(a)

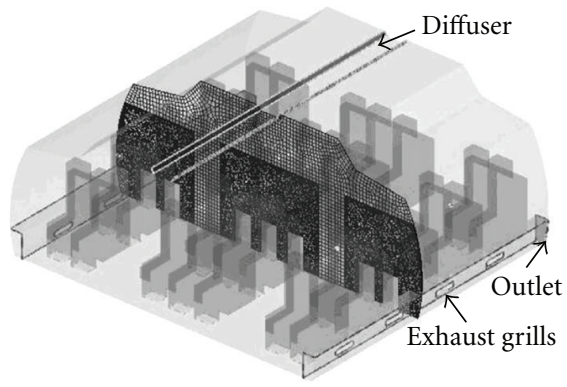

(b)

FIGURE 5: Study of the airborne transport of expiratory droplets in a Boeing 767-300 cabin mockup. (a) General view of the mockup with the passenger dummies (b) Computational dominium [20].

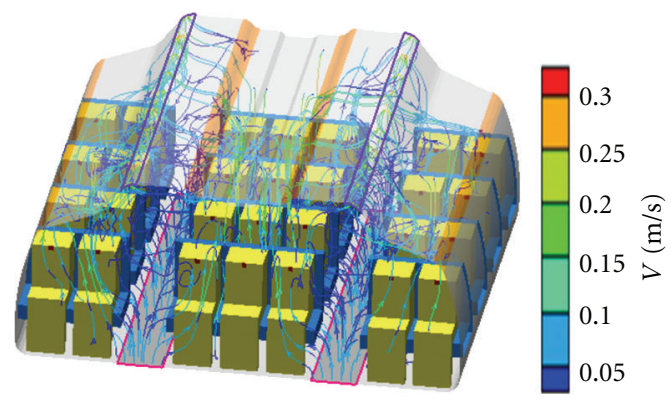

(a)

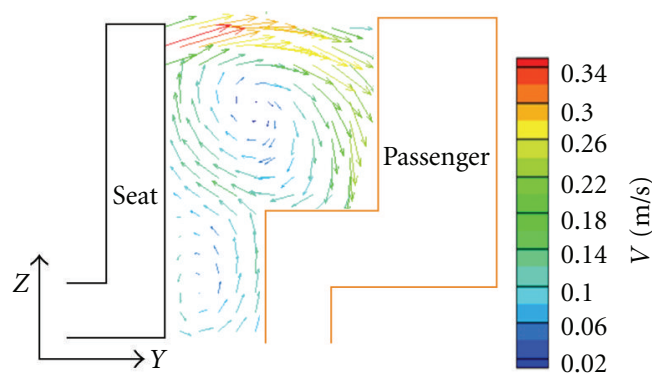

(b)

FIgURe 6: CFD study inside B767-300 cabin. (a) Cabin geometry. (b) PV integrated to the back of the cabin seats [9].

with an initial velocity of $20 \mathrm{~m} / \mathrm{s}$ during $0.5 \mathrm{~s}$, aiming at simulating a horizontal sneezing. The equations applied to model the liquid particles were similar to the ones applied to simulate the gaseous particles, including the gravitational effect, not considered for the gases. A semiempirical model was applied to represent the liquid particles adhering effect to solid surfaces, and it was taken into account the thermophoretic, Brownian, and lift Staffman forces.

They have concluded that the expiratory droplets, originated from a sneezing, could travel a distant larger than three rows, although the most quantity of particles were deposited onto internal cabin surfaces, rather than being ventilated out. Concerning the analyzed ventilation solutions, it was observed that $\mathrm{PV}$ combined with mixing ventilation could shield up to $60 \%$ of the contaminants that reached the user without PV. Likewise Zhang and Chen [9],Gao and Niu [18] also did not perform experimental validation.

\subsection{Particle Generators Studies}

2.4.1. Monodispersed Particle Generators. Shimada et al. [43] have studied the dispersion of fine particles inside a ventilated mockup with CFD numerical simulations and measurements, aiming at investigating the influence of the particle's releasing point location (Figure 8 ). Around $3 \cdot 10^{10}$ particles of latex polystyrene per cubic meters of air with a medium size of $0.14 \mu \mathrm{m}$ were released by the emission port into the room with an airflow of $1 \mathrm{~L} / \mathrm{min}$. An in-house made monodispersed particle generator composed basically by a pump, a nebulizer, and a drier was used. Cupper tubes' with $6 \mathrm{~mm}$ in diameter were applied to sample air from the room and guide it till two optical particle counters, as the volume occupied by the equipment could disturb the airflow if located inside the mockup. The sampling tubes' suction airflow was varied as well as the tubes length, but no effect on the measurements was found.

The authors have not obtained good numericalexperimental correlations when the emitter was close to the wall due to its effects on particle dynamics. In the end of the analysis, they have increased the grid by an $8 \mathrm{x}$ factor and have obtained similar results for velocity field, but not so similar for concentration. The authors believe it could be explained by the fact of larger discrete volumes having higher particle numerical diffusion.

Zhang et al. [42] have studied the dispersion of airborne particles in an aircraft mockup (Figure 9) focusing on the air velocities, temperatures, and contaminants' concentration fields. Expiratory contaminants were simulated with tracer gas $\left(\mathrm{SF}_{6}\right)$ and with a monodispersed $0.7 \mu$ m medium-size TSI model 3475-particle generator. Both gaseous and liquid particles were injected through tubes into the cabin. The airflow was solved with RANS and RNG k- $\varepsilon$ turbulence model, and the dispersed phase considered in a Lagrangean frame. Not so good numerical-experimental correlations were obtained for the velocities and concentration fields, mainly due to 


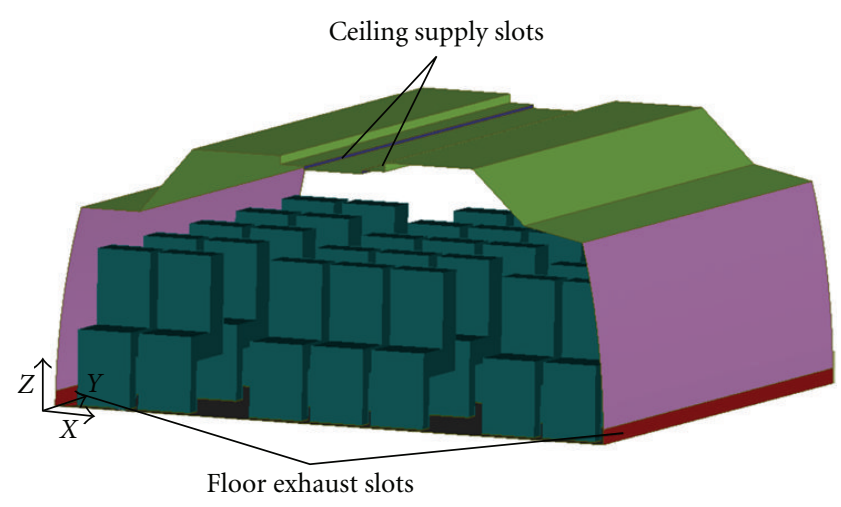

(a)

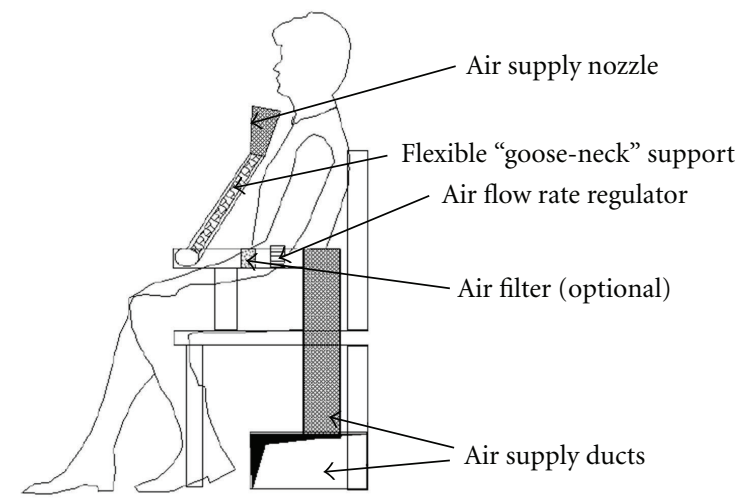

(b)

Figure 7: (a) Cabin geometry showing ceiling supply and floor exhaust slots. (b) PV integrated to an aircraft cabin seat armrest [18].

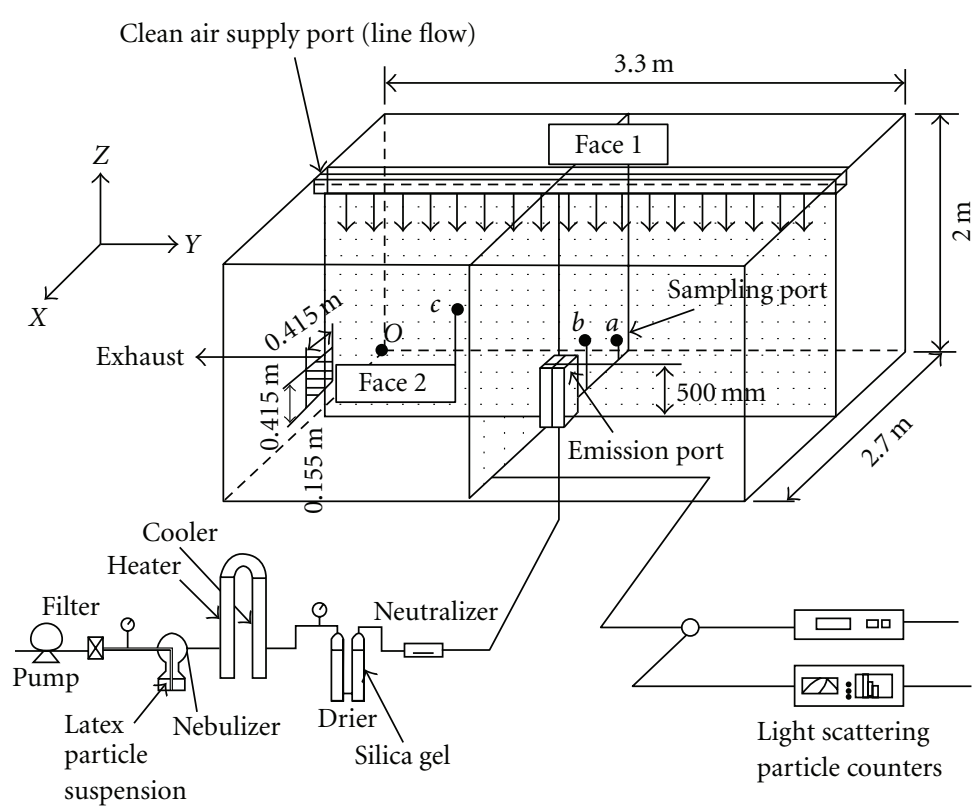

Positions of sampling ports

$(X, Y, Z)(\mathrm{m})$

$a:(0.23,1.65,0.15)$

$b:(1.14,1.65,0.62)$

$c:(0.23,0.6,0.64)$

$\Xi$

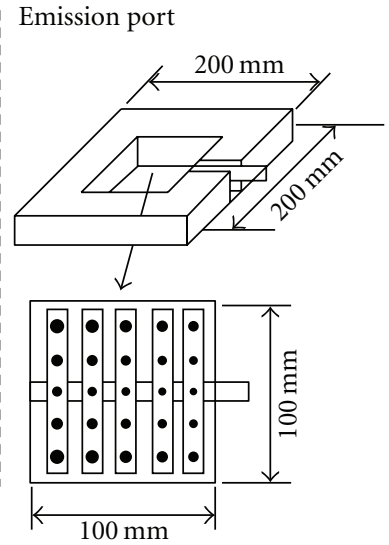

FIGURE 8: Ventilated room, particle generating, and measuring systems [43].

uncertainties to measure the diffusers outlet air velocity, used as boundary condition in the CFD simulation. The authors have observed that the velocity measurement process is a key factor, to study the transport of airborne particles, and also a challenge. Gupta et al. [44] have simulated with CFD the spread of expiratory droplets inside a fully occupied twin-aisle aircraft cabin, as shown in Figure 10(a). The boundary condition of the index passenger (located in the center of the cabin) was different depending if he was coughing, breathing, or talking. They have simulated three distinct cases: a single cough, a single breath, and a 15second long talking, considering monodispersed expiratory droplets, having diameters of $8.5 \mu \mathrm{m}, 0.4 \mu \mathrm{m}$, and $30 \mu \mathrm{m}$, respectively. The mouth of the rest of the passengers were considered closed, and their noses opened, with a random breathing distribution as shown in Figure 10(b).

The CFD simulations have applied RANS to calculate the airflow with $\mathrm{k}-\varepsilon$ RNG turbulence model, and the contaminants were analyzed in a Lagrange frame. Two grids were tested, one with 1.5 million and the other with 10 million tetrahedral elements. As the differences in the results were minor, the coarser one was used, which has $5 \mathrm{~mm}$ size on mouth, nose, and face of the passengers, $20 \mathrm{~mm}$ on the rest of the body, and $40 \mathrm{~mm}$ elsewhere. In the first $30 \mathrm{~s}$ of simulation, most of the droplets were transported within one row of the index occupant, and then spread all over the seven-row cabin in a uniform particle distribution in 4 minutes. The authors have considered their results were in agreement with other studies found in the literature but have mentioned that a controlled experiment study is still required to identify the limitations of the applied CFD methods.

2.4.2. Polydispersed Particle Generators. The polydispersed particle generators found in the market (RR Elektronic, ATI, GRIMM, TSI, PIVTEC, Spraying System, etc.), in general, produce particles having around $0.3 \mu \mathrm{m}$ of medium 


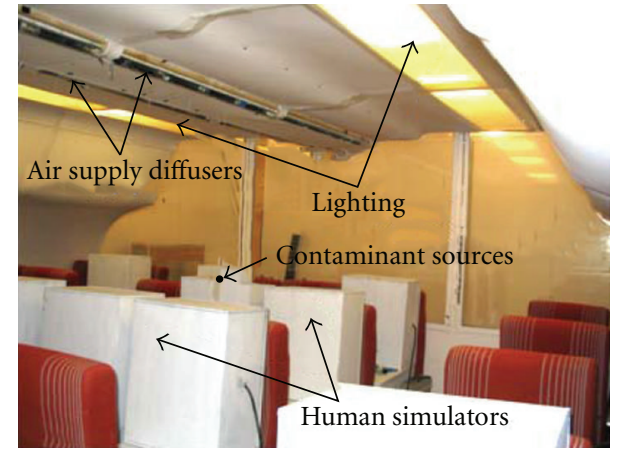

(a)

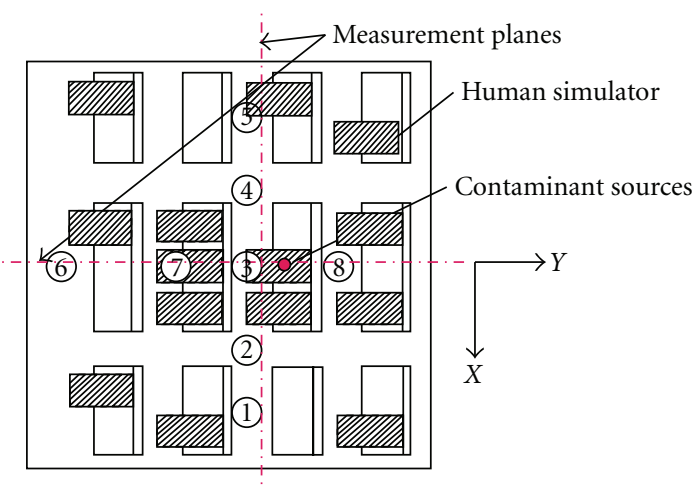

(b)

FIgURE 9: Aircraft cabin mockup to study the dispersion of expiratory particles. (a), the interior of the mockup. (b), top view with measurement planes [42].

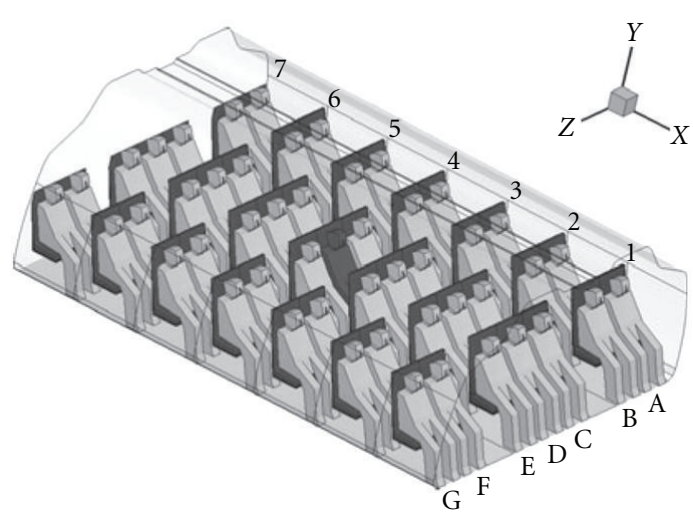

(a)

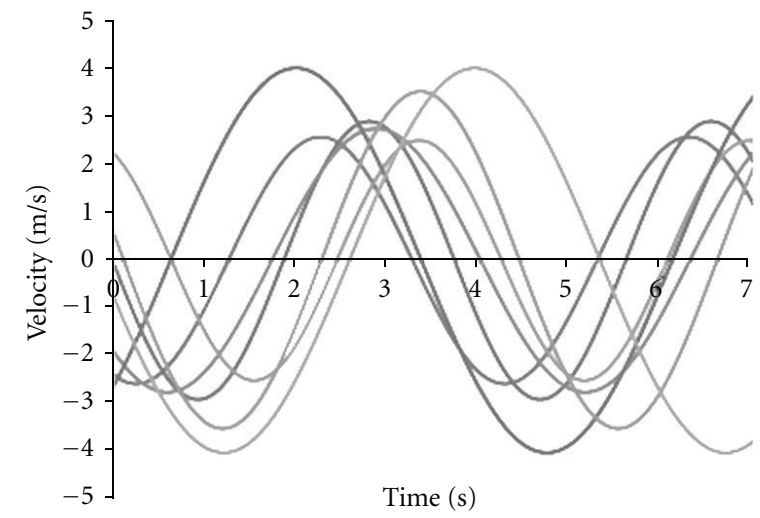

(b)

FIGURE 10: (a) Fully occupied aircraft cabin, with the index passenger in the center. (b) Random breathing curves considered at the nose of passengers [44].

diameter, which is too small to simulate expiratory droplets, considering the Duguid [34] measured particle size distribution as the target. The fact of not finding off-the-shelf polydispersed generator to produce particles comparable to expiratory droplets may have motivated researchers to use an inhouse-made generator able to mimic human coughing [13]. This generator is fed with compressed air and liquid similar to human saliva (Figure 11) and was calibrated based on the Duguid [34] particle size distribution.

Wan et al. [41] have applied the just cited particle generator to evaluate the dispersion of droplets inside a ventilated aircraft mockup. The particle size distribution was characterized with a light scattering spectrometer (PMS Lasair 1002) located $10 \mathrm{~mm}$ next to the injection nozzle, resulting in a peak concentration of $2.5 \times 10^{6}$ particles/L at a medium size of $6.75 \mu \mathrm{m}$. Distilled water was injected with compressed air, producing air velocity at the nozzle of about $10 \mathrm{~m} / \mathrm{s}$. Based on the measurement with volunteers conducted by Zhu et al. [47], this air velocity at the nozzle is apparently adequate to simulate human coughing. Particles were detected one row distant from the injection point in the longitudinal direction, and 3 rows distant in the lateral direction, what could be explained by the cabin's airflow profile. They have also observed that the cabin contaminant concentration is inversely proportional to the fresh air flow rate. The relative humidity of the cabin was controlled in the range of 5 to $25 \%$, and the peak of detection occurred for the higher cabin humidity values, explained by the lower droplets evaporation ratio.

Similar study was developed by Sze To et al. [13] where the focus was to characterize the dispersion of expiratory droplets inside an aircraft cabin with mixing ventilation, as well as to understand the effects of the cabin air changes on the dilution and removal of these particles. This study was carried out in an aircraft cabin mockup (Figure 12) built inside ICIEE (International Center for Indoor Environment and Energy), at the Technical University of Denmark (DTU). During the experiments, the cabin was kept without recirculation and pressurized with $7 \mathrm{~Pa}$ to avoid any kind of infiltration. Heated cylinders were added to simulate passengers' thermal dissipation, PIV was used to characterize the particle generator initial jet air velocity during one coughing and spectrometers to characterize particles. The method called fluorescence dye technique was applied to 


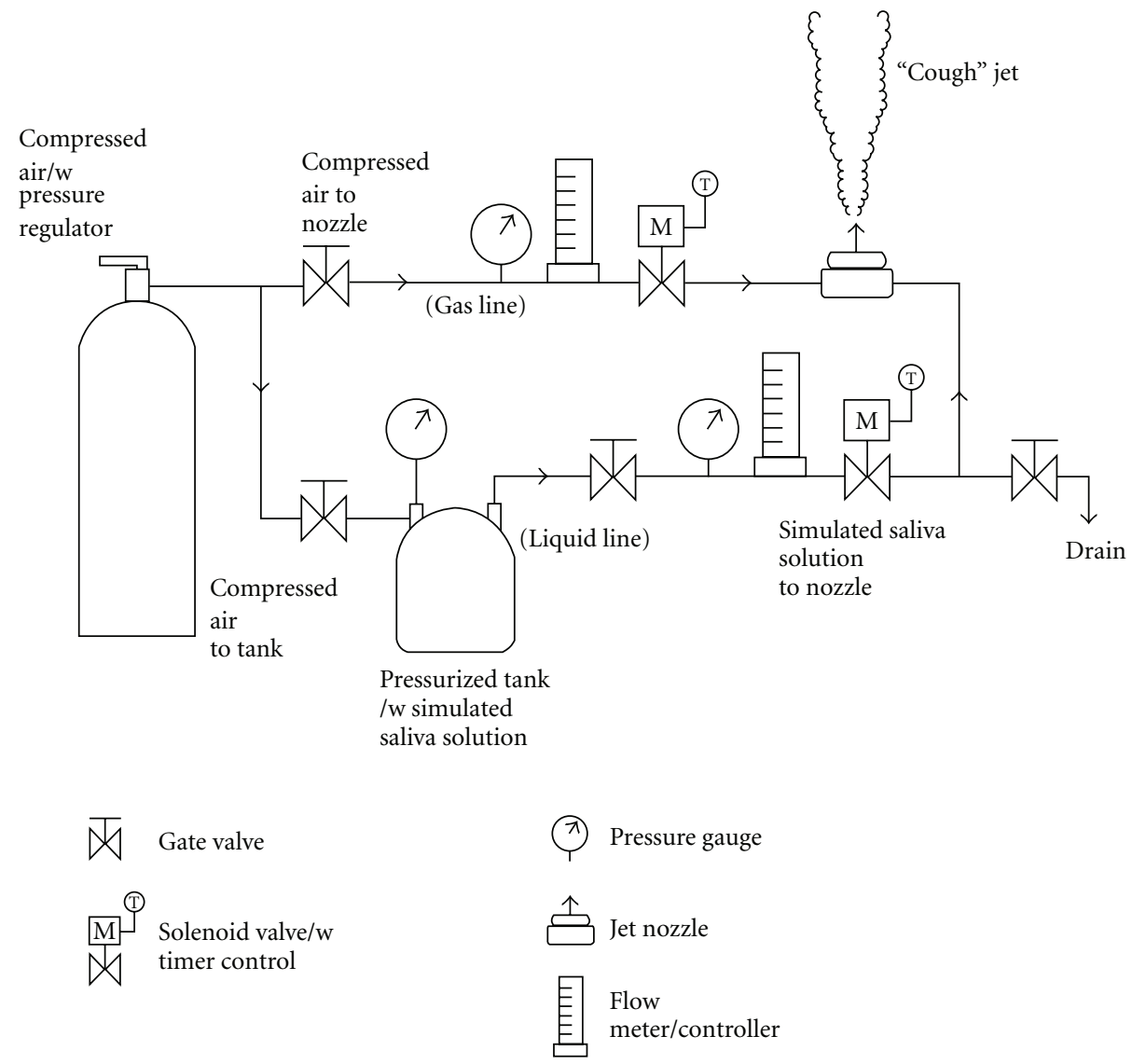

FIGURE 11: Inhouse-made polydispersed particle generator, built to mimic expiratory droplets produced during human coughing [48].

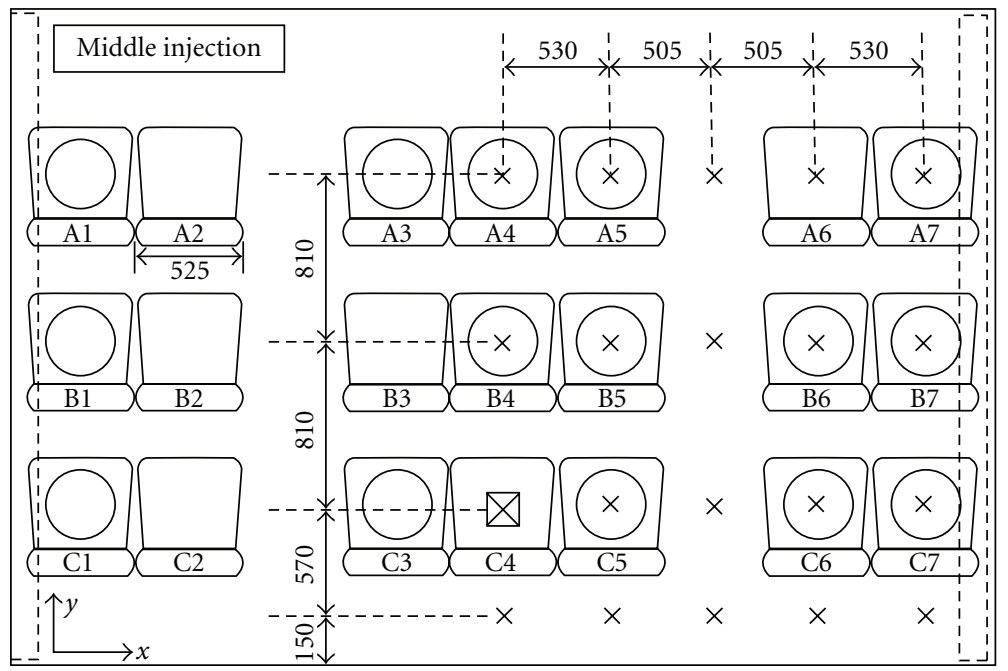

\footnotetext{
Heating cylinder (manikin)

$\otimes$ Injection point

$\times$ Aerosol measurement point
}

FIgURE 12: ICIEE cabin mockup with 21 seats [13]. 
measure particle deposition on internal surfaces. Since there was one spectrometer only, the experiment was repeated several times to measure the various points and to assess reproducibility.

Results have shown that increasing the fresh airflow rate decreases the particle concentration nearby the injection point due to the dilution effect. On the other hand, the particle dispersion is increased, helping to raise the concentration near the seats located more distant. This study has also confirmed that the particles fate is totally dependent on their sizes, and it obtained particles deposition rates in the range from 60 to $70 \%$.

Table 3 summarizes some aspects of the methods discussed and other studies also reviewed. Great part of them was developed inside ventilated rooms and aircraft cabin mockups, and the majority focused on expiratory contaminants. Different off-the-shelf monodispersed atomizers have been applied, but the polydispersed atomizers were inhousemade types, as already discussed. To simulate small particles (droplet nuclei) as well as gaseous pollutants, researchers have applied tracer gases such as $\mathrm{SF}_{6}$ and $\mathrm{CO}_{2}$. According to the last column, the researchers have applied CFD to simulate particles by using the Euler or Lagrange equations and in most cases RANS with k- $\mathrm{k}$ RNG turbulence models.

The studies discussed so far have simulated the dispersion of contaminants inside ventilated spaces considering the occupants seated in a static conditions. However, some studies have indicated that the contaminant's personal exposure is significantly influenced by the occupants' movement [51, 52]. In parallel, in order to reduce complexity, some authors have studied the dispersion of contaminants inside smallscaled water models in ventilated buildings [53].

Motivated by those studies, Poussou et al. [49] have represented an aircraft cabin with a small-scale water model as shown in Figure 13, aiming at studying the influence of body movement on flow and contaminant distribution inside mock-up cabins, with and without ventilation. They have applied PIV to measure the velocity field and PLIF (Planar Laser-Induced Fluorescence) to visualize the contaminant concentration and have developed a companion CFD model to be validated based on the reduced mock-up experiment results. Basically, the CFD models were developed inside Fluent, considering RANS with k- $\varepsilon$ RNG turbulence models, and it applied a combined dynamic (with 0.25 million cells) and static (with 4.4 million cells) mesh scheme.

The authors have observed that the contaminants were able to reach higher vertical locations in the case with the ventilation turned on and that the CFD simulation reasonably captured this airflow velocities' basic difference between both simulated conditions.

\section{Discussion}

The reviewed studies have applied tracer gas and particle atomizers to study transport of expiratory contaminants. Based on those, a preliminary method to evaluate air dis-tribution philosophies in terms of indoor air quality is proposed as follows.
First of all, it is important to understand the physical process one's intend to reproduce in the experiment in order to specify the type of pollutant and its main characteristics (Figure 14, step 1). For instance, if the intention is to assess the dispersion of $\mathrm{CO}_{2}$ released during breathing, a gas source with the same airflow as the human average $\mathrm{CO}_{2}$ exhalations could be used, as done recently $[9,47,54]$. But, if the transient effect of the breathing, for any reason, should be taken into account, a gas-releasing control device should be used, such as the breathing simulator applied by Nielsen [15] andHalvonová and Melikov [55] or the breathing numerical model developed by Gupta et al. [44]. Differently, if one intends to study the spread of expiratory droplets generated during any expiratory activity, it is necessary to define an aerosol to mimic saliva particle size distribution and the activity-releasing initial velocity. The particle generator used by Zhang et al. [42] seems adequate to simulate expiratory activities, as it is capable of generating particles in the range of 0.1 to $8 \mu \mathrm{m}$, which encloses the most common particle size generated by expiratory activities (Figure 3). Sze To et al. [13] have developed an inhouse-made polydispersed particle generator to mimic human coughing (Figure 11) and have calibrated the equipment based on the coughinggenerated particle size distribution measured by Duguid [34] and the releasing velocities measured by Zhu et al. [47]. It is also possible to dilute benign microorganism into the aerosol solution, aiming at assessing the microorganism survivability in an airborne state as done by Sze To et al. [56]. Finally, it is important to add that the accurate description and standardization of the expiratory activities (breathing, speaking, coughing, and sneezing) are important for comparison of results of different studies. Melikov [57] has already reported standardization for breathing.

Depending on the specific needs, the phenomenon could be treated as steady state or transient. Thatcher et al. [58] focused on determining the particles' deposition rate after a puff release of compressed air, which is intrinsically transient. On the other hand, Zhang and Chen [25] have evaluated different types of building ventilation systems based on the dispersion of contaminants generated by a continuousflow particle atomizer. This definition shall be made soon (Figure 14, step 2), because it may affect the equipment selection.

Once defined the contaminants of interest and their generation physical process, the contaminant generation method should be defined (Figure 14, step 3). Based on the literature review, tracer gas and/or liquid/solid particle generators have been applied. When the studied contaminant is gaseous, naturally the tracer gas method has been applied. The $\mathrm{SF}_{6}$ has been the most applied, mainly because it is a nonreactive, nontoxic, odourless, colourless, and is detectable in small concentration and by well-know and reliable instruments [16]. Tracer gas has been applied to simulate the spread of small expiratory droplets as well (less than $5 \mu \mathrm{m}$ ). However, this possibility should be considered only if the particle adherence effect onto surfaces could be neglected, as discussed in Section 2.2. Otherwise, a particlegenerator device should be used. When applying off-the- 
TABLE 3: Studies related to airborne dispersion of contaminants and some methods' aspects.

\begin{tabular}{|c|c|c|c|c|c|}
\hline Reference & Test place & $\begin{array}{c}\text { Simulated } \\
\text { contaminant }\end{array}$ & Tracer & Equipments & Particle simulation \\
\hline $\begin{array}{l}\text { Zhang and Chen [9] } \\
\text { Num }\end{array}$ & Aircraft cabin & Breathing pollutants & Gas $\mathrm{CO}_{2}$ & N/A & $\begin{array}{l}\text { CFD Euler k- } \varepsilon, \\
\text { RNG } \\
\end{array}$ \\
\hline $\begin{array}{l}\text { Sze To et al. [13] } \\
\text { Exp }\end{array}$ & Aircraft cabin & $\begin{array}{l}\text { Expiratory droplets } \\
\text { (coughing) }\end{array}$ & $\begin{array}{c}\text { Polydispersed } \\
\text { particles of } \\
\text { simulated saliva } \\
\end{array}$ & $\begin{array}{l}\text { Inhouse atomizer; } \\
\text { spectrometer }\end{array}$ & N/A \\
\hline $\begin{array}{l}\text { Nielsen [15] } \\
\text { Exp }\end{array}$ & Ventilated room & $\begin{array}{l}\text { Expiratory } \\
\text { pollutants }\end{array}$ & Gas $\mathrm{N}_{2} \mathrm{O}$ & $\begin{array}{c}\text { Gas source and } \\
\text { analyzer }\end{array}$ & N/A \\
\hline $\begin{array}{l}\text { Bryant et al. [19] } \\
\text { Num and Exp } \\
\end{array}$ & Ventilated room & $\begin{array}{c}\text { General indoor } \\
\text { contaminants }\end{array}$ & $\begin{array}{c}\text { Monodispersed } \\
\text { particles with } 3 \mu \mathrm{m}\end{array}$ & $\begin{array}{c}\text { TSI atomizer; Laser } \\
\text { photometer }\end{array}$ & CFD Lagrange \\
\hline $\begin{array}{l}\text { Yan et al. [20], } \\
\text { Num and Exp }\end{array}$ & Aircraft cabin & $\begin{array}{l}\text { Expiratory droplets } \\
\text { (droplet nuclei) }\end{array}$ & Gas $\mathrm{CO}_{2}$ & $\begin{array}{l}\mathrm{CO}_{2} \text { source and } \\
\text { monitor. VPTV }\end{array}$ & $\begin{array}{c}\text { CFD Euler } \\
\mathrm{k}-\varepsilon, \text { std }\end{array}$ \\
\hline $\begin{array}{l}\text { Wan et al. [41] } \\
\text { Exp }\end{array}$ & Aircraft cabin & $\begin{array}{l}\begin{array}{c}\text { Expiratory droplets } \\
\text { (coughing) }\end{array} \\
\end{array}$ & $\begin{array}{l}\text { Water polydispersed } \\
\text { particles with } 6.7 \mu \mathrm{m}\end{array}$ & $\begin{array}{l}\text { Inhouse generator; } \\
\text { CNC; spectrometer }\end{array}$ & N/A \\
\hline $\begin{array}{l}\text { Zhang et al. [42] } \\
\text { Num and Exp }\end{array}$ & Aircraft cabin & $\begin{array}{l}\text { Expiratory } \\
\text { contaminants }\end{array}$ & $\begin{array}{c}\text { DEHS } \\
\text { monodispersed } \\
\text { particles } 0.7 \mu \mathrm{m} ; \\
\mathrm{SF}_{6} ;\end{array}$ & $\begin{array}{l}\text { TSI atomizer and } \\
\text { counter; gas sampler }\end{array}$ & $\begin{array}{l}\text { CFD Lagrange } \\
\text { k- } \varepsilon, \text { RNG }\end{array}$ \\
\hline $\begin{array}{l}\text { Shimada et al. [43] } \\
\text { Num and Exp }\end{array}$ & Ventilated room & Fine-particles smoke & $\begin{array}{c}\text { polystyrene latex } \\
\text { with } 0.14 \mu \mathrm{m}\end{array}$ & $\begin{array}{l}\text { Inhouse atomizer; } \\
\text { particle counter }\end{array}$ & CFD Euler \\
\hline $\begin{array}{l}\text { Gupta et al. [44] } \\
\text { Num }\end{array}$ & $\begin{array}{l}7 \text { Row, twin-aisle, } \\
\text { full-occupied } \\
\text { aircraft cabin }\end{array}$ & $\begin{array}{l}\text { Expiratory droplets } \\
\text { (coughing, } \\
\text { breathing, and } \\
\text { talking) }\end{array}$ & $\begin{array}{c}\text { Monodispersed } \\
\text { particles, with } \\
\text { diameters of } 8.5 \mu \mathrm{m} \text {, } \\
0.40 \mu \mathrm{m} \text {, and } 30 \mu \mathrm{m}\end{array}$ & N/A & $\begin{array}{c}\text { CFD Lagrange k- } \varepsilon, \\
\text { RNG }\end{array}$ \\
\hline $\begin{array}{l}\text { Poussou et al. [49] } \\
\text { Num and Exp }\end{array}$ & $\begin{array}{l}\text { Aircraft cabin, } \\
\text { reduced-scale } \\
\text { mockup }\end{array}$ & $\begin{array}{c}\text { General pollutants } \\
\text { released/spread by a } \\
\text { moving body }\end{array}$ & $\begin{array}{c}\text { Uranine } \\
\left(\mathrm{C}_{20} \mathrm{H}_{10} \mathrm{O}_{5} \mathrm{~S}_{2} \mathrm{Na}\right)\end{array}$ & PIV and PLIF & CFD k- $\varepsilon$, RNG \\
\hline $\begin{array}{l}\text { Wan et al. [50] } \\
\text { Num }\end{array}$ & Aircraft cabin & $\begin{array}{l}\text { Expiratory droplets } \\
\quad \text { (coughing) }\end{array}$ & $\begin{array}{c}\text { Monodispersed } \\
\text { water droplets, with } \\
\text { diameters of } 2,6,12 \text {, } \\
\text { 20, } 28,45,87.5 \\
\text { 137.5, and } 225 \mu \mathrm{m}\end{array}$ & N/A & $\begin{array}{l}\text { CFD Lagrange } \\
\text { k- } \varepsilon, \text { RNG }\end{array}$ \\
\hline
\end{tabular}

Num = numerical; Exp = experimental; N/A = Not applicable.

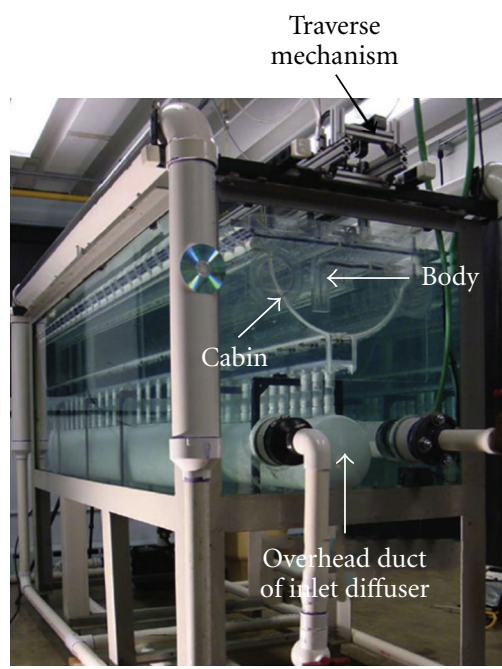

(a)

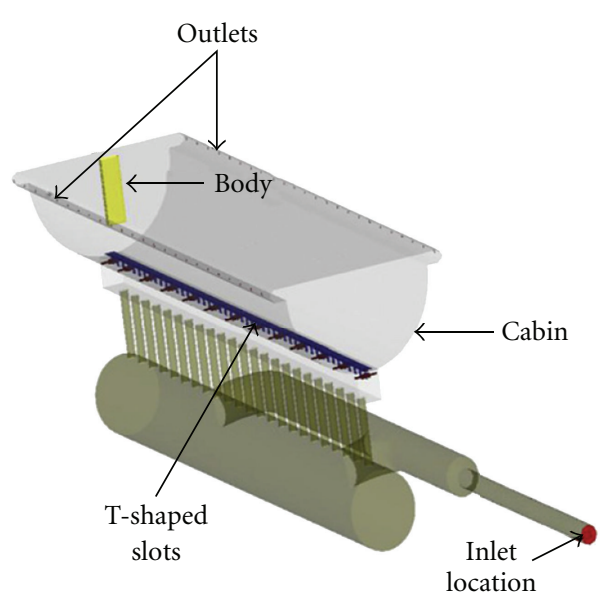

(b)

FIGURE 13: (a) Small-scale experiments test facility that simulates a aircraft cabin. (b) 3D digital geometry of the facility to be used in the CFD models [49]. 


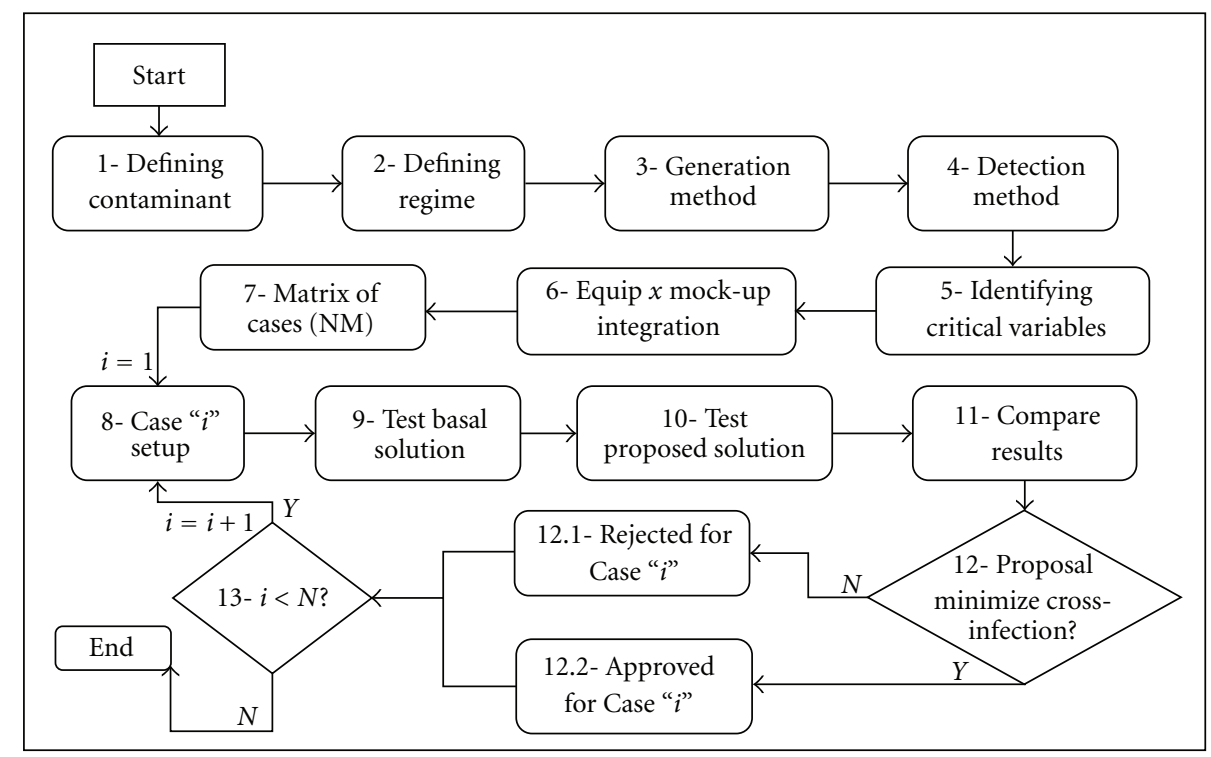

FIGURE 14: Method to evaluate the response of air distribution solutions for indoor air quality.

shelf generators, the particle size is often characterized by their manufacturers. On the other hand, to use inhousemade generators, it is required to characterize the particles generated with adequate and usually complex measuring method such as the Interferometric Mie Imaging (IMI), as applied by Yang et al. [16] and Sze To et al. [13]. Particle counter might not be used instead, mainly due to the high particle concentration in the generator outlet jet, which may cause major coincidence losses. If the scope is gaseous, contaminants or small droplets (droplet nuclei) and the surface adherence effect after contact can be neglected, tracer gas could be applied.

Regarding the detection method (step 4), gas sensors have been used to measure tracer gas concentration, such as the nondispersive infrared $\mathrm{CO}_{2}$ sensors used by Yan et al. [20] or the photoacoustic $\mathrm{SF}_{6}$ analyser used by Zhang et al. [42]. Their calibration validity, accuracy, and time constant are important parameters, not always sufficiently discussed in the articles. In order to measure particle concentration, most researchers have applied optical counters $[25,43,59]$, usually capable of measuring the particles' number concentration in 5-16 channels [60] or aerosol spectrometers [13, 16, 42], which can additionally measure the aerosol mass concentration. According to Hinds [60], the optical particle counters have counting efficiencies (ratio of indicated count to true count) of around $100 \%$ for particles larger than $0.1 \mu \mathrm{m}$, and their response depends basically on the size and refractive index of the particles. As these counters are commonly sizecalibrated with monodispersed polystyrene latex particles [60], the error in size estimation when measuring particles with different refractive index can be significant $[60,61]$. Another important aspect is the equipment sampling time, which should be specified according to the experiments' specific characteristics (if steady state or transient, time scales, needed response time, etc.), as briefly discussed by
Wan et al. [41]. It is important to define if CFD validation will be done during this step as well, because it may require specific instrumentation such as PIV, as applied by Sze To et al. [13], or PLIF, as applied by Poussou et al. [49].

As per step 5 , it is important to identify the variables that could influence the results of the experiment significantly, herein called critical variables. These variables should be monitored and/or controlled in order to guarantee the experiments' adequate reproducibility, what is of fundamental importance due to the typical limitations in the number of measuring equipments and also the high number of variables to be studied, one each time.

It is well known that the airflow velocity field influences directly the contaminant concentration field. So, all the variables that may affect the air velocities field should be controlled, such as the air exchange rate and the recirculation rate, the air and internal surfaces temperature, the air inflow temperature, the volume occupied by the room furnishings such as seats and human simulators, and their thermal dissipation rates, the cabin diffusers flow split and their inflow turbulence level, the air return area, which influences the inboard-outboard pressure differential and thus the infiltration levels, and so forth. Sze To et al. [13] have shown that increasing the fresh airflow rate decreases the particle concentration nearby the injection point due to the dilution effect. On the other hand, the particle dispersion is increased, helping to raise the concentration near the seats located more distant. Experimental studies have shown that the chair design, the human-simulator clothing thermal insulation, and the human-simulator geometry have significant impacts on the generated thermal plume $[62,63]$. Further, the occupants' thermal plume itself, as per Stancato [64], indeed influences the air velocities field inside aircraft cabins. Thus, all the parameters that could affect the human-simulator thermal plumes should be considered when studying the indoor airborne dispersion of contaminants. 
Another important variable is the indoor airs' relative humidity, as it affects the evaporation and/or condensation ratio of liquid aerosols and, therefore, could influence the particles dynamics. Morawska [65] has shown that distilled water droplets take 5 times more to evaporate when moved from a $0 \%$ relative humidity environment to another with $80 \%$. Inside aircraft cabins, Wan et al. [41] have measured the droplets' detection peak when considering the higher air relative humidity, explained by the reduction in droplets evaporation. Other critical variables to be considered to study the spread of airborne expiratory droplets inside ventilated spaces are the furnished area (as shown by Thatcher et al. [58]), contaminant particle sizes, (as discussed by Wan et al. [50]), the contaminant initial velocity (Morawska [65]), and at last the air distribution philosophy $[9,18,66]$.

The identification of the critical variables is important not only for the experiment reproducibility, but also when one intends to compare experimental with simulation results. Zhang et al. [42] have applied anemometers to measure the velocity magnitude at cabin diffusers and smoke to estimate the velocity direction. The authors believe this might have been the main reason to have differences between numerical results and measurements for contaminants concentration. To avoid this kind of discrepancies, Sze To et al. [13] have applied PIV to measure aircraft cabin air velocities, and, based on that, Wan et al. [50] have obtained good correlations between CFD simulation and measurements.

Once defined the contaminant of interest, the generation and measuring methods, the critical variables of the experiment, and the equipment integration into the mockup shall be done (step 6). In this step, the main tasks are to define the point of contaminant releasing, as well as the measurements points. When the equipment sizes are considerable and may affect the airflow distribution field, they might be placed outside the experimental chambers. In such a case, both particle injection and particle sampling shall be made by means of small-diameter tubes. In this case, a sensitivity analysis should be done to evaluate if the tubes' geometry impacts on measurements, as done by Shimada et al. [43]. In addition, the sampling airflow suction, the sampling tube diameter, the airflow air velocities, and the relative position between the counter and the airflow should also be investigated in order to minimize further particle detections' inaccuracy [60].

During the case matrix definition (step 7), it is important to take into account statistical criteria as well as the equipment limitations to specify each experiment details and their repetitions. Zhang et al. [42] have sampled particles during 30 seconds and repeated 10 times each measurement. Sze To et al. [13] had one spectrometer only, and the experiment was repeated several times to measure the various points and to assess reproducibility. After that, the case setup is made (step 8), and the basal solution tested first in order to obtain baseline results (step 9). Then, the proposed solution is tested (step 10), and both results are compared (step 11). Finally, it is possible to assess if the solution is approved for the case under evaluation, that is, if the proposed solution minimizes cross-infection or not (step 12).

\section{Conclusions}

A review of methods to study dispersion of airborne expiratory contaminants was presented and discussed. In general, researchers have applied tracer gas or particle generators to reproduce contaminant generation in scientific studies. There are not many available off-the-shelf particle generators capable of reproducing human expiratory droplets. Taking into account the current state of the art of expiratory droplets' size distribution, the off-the-shelf monodispersed particle generator seems adequate, although the polydispersity characteristic of the expiratory droplets cannot be reproduced in this case, and each particle size needs to be studied separately. In order to generate polydispersed expiratory droplets, the unique option seems to be the construction of an in-house particle generator, what is far from being an easy task basically due to the difficulties to calibrate the generated particle size distribution.

The most used computational methods to study the spread of airborne expiratory droplets inside aircraft cabin has been CFD simulations. Most of the users have applied Euler models to analyze the steady-state intrinsic physical phenomenon and Lagrange for transient ones. Good agreement levels have been shown between experiment and numerical results, mainly for temperature and velocities fields, but it is still strongly dependent on the applied measurement technique. Usually, PIV is the most applied method that has guaranteed a minimum and adequate level of agreement. For the contaminant concentration fields, some studies have reached good agreement levels, but they are not many.

Based on the presented paper, it was possible to preliminarily identify the main equipments needed to study the spread of airborne expiratory contaminants inside aircraft cabins, a variety of requirements involved, as well as to initiate the discussion of a method to be applied to evaluate aircraft ventilation solutions in terms of indoor air quality. The proposed method may still be enhanced, but it probably can be already applied as a guide for studies related to airborne cross-infection inside aircraft cabin and inside other ventilated spaces as well.

\section{Acknowledgments}

The authors M. L. Pereira and A. Tribess wish to acknowledge $\mathrm{CNPq}$ (Brazilian National Research Council) for the research support and grant of fellowship.

\section{References}

[1] M. Cupa, "Air transport, aeronautic medecine, health," Bulletin de l'Academie Nationale de Medecine, vol. 193, no. 7, pp. 1619-1631, 2009.

[2] D. S. Walkinshaw, "Germs flying and the truth," ASHRAE Journal, vol. 52, no. 4, pp. 70-73, 2010.

[3] D. Fishbein, H. L. Kirking, J. Cortes et al., "Practical caseresponse approaches to investigating the spread of disease in airports and on aircraft," in Proceedings of the Research on the Transmission of Disease in Airports and on Aircraft Conference, 
no. 47, Transportation Research Board of the National Academies, Washington, DC, USA, 2010.

[4] S. J. Olsen, H. L. Chang, and T. Y. Cheung, "Transmission of the severe acute respiratory syndrome on aircraft," New England Journal of Medicine, vol. 349, no. 25, pp. 2416-2422, 2003.

[5] A. Mangili and M. A. Gendreau, "Transmission of infectious diseases during commercial air travel," Lancet, vol. 365, no. 9463, pp. 989-996, 2005.

[6] B. G. Wagner, B. J. Coburn, and S. Blower, "Calculating the potential for within-flight transmission of influenza A (H1N1)," BMC Medicine, vol. 7, no. 81, 2009.

[7] M. Connor, "Transmission of diseases and long-haul flights," in Proceedings of the ICE International Aviation Conference, NHS Dumfires \& Galloway, Scotland, UK, 2009.

[8] T. Zhang and Q. Chen, "Comparison of different ventilatin systems for commercial aircraf cabine," in Proceedings of the International Conference on Indoor Air Quality and Climate, vol. 4, pp. 3205-3210, Beijing, China, 2005.

[9] T. Zhang and Q. Chen, "Novel air distribution systems for commercial aircraft cabins," Building and Environment, vol. 42, no. 4, pp. 1675-1684, 2007.

[10] E. H. Hunt and D. R. Space, "The airplane cabin environment, Boeing company," in Proceedings of the International InFlight Service Management Organization Conference, Montreal, Canada, 1994.

[11] "Air quality for commercial aircraft cabin particulate contaminants," Aerospace Information Report SAE AIR 4766/1, SAE Aerospace, 2005.

[12] ASHRAE, ASHRAE Handbook: Heating, Ventilating, and AirConditioning Applications, Chapter 10: Aircraft, American Society of Heating, Ventilating and Air Conditioning Engineers, Atlanta, Ga, USA, 2007.

[13] G. N. Sze To, M. P. Wan, C. Y. H. Chao, L. Fang, and A. Melikov, "Experimental study of dispersion and deposition of expiratory aerosols in aircraft cabins," Aerosol Science and Technology, vol. 43, no. 5, pp. 466-485, 2009.

[14] R. Li, S. C. Sekhar, and A. K. Melikov, "Thermal comfort and IAQ assessment of under-floor air distribution system integrated with personalized ventilation in hot and humid climate," Building and Environment, vol. 45, no. 9, pp. 1906-1913, 2010.

[15] P. V. Nielsen, "Analysis and design of room air distribution systems," HVAC and R Research, vol. 13, no. 6, pp. 987-997, 2007.

[16] S. Yang, G. W. M. Lee, C. M. Chen, C. C. Wu, and K. P. Yu, "The size and concentration of droplets generated by coughing in human subjects," Journal of Aerosol Medicine, vol. 20, no. 4, pp. 484-494, 2007.

[17] P. V. Nielsen, E. Barszcz, T. Czarnota et al., "The influence of draught on a seat with integrated personalized ventilation," in Proceedings of the International Conference on Indoor Air Quality and Climate, Technical University of Denmark, Copenhagen, Denmark, Paper ID: 247, 2008.

[18] N. P. Gao and J. L. Niu, Personalized Ventilation for Commercial Aircraft Cabins, The Hong Kong Polytechnic University, Kowloon, Hong Kong, 2007.

[19] J. R. Bryant, A. D. Eisner, L. A. Brixey, and R. W. Wiener, "Transport of airborne particles within a room," Indoor Air, vol. 16, no. 1, pp. 48-55, 2006.

[20] W. Yan, Y. Zhang, Y. Sun, and D. Li, "Experimental and CFD study of unsteady airborne pollutant transport within an aircraft cabin mock-up," Building and Environment, vol. 44, no. 1, pp. 34-43, 2009.
[21] D. S. Walkinshaw, Passenger Aircraf Ventilation System Design Challenges and Solutions, Indoor Air Technologies Inc., 2005.

[22] Q. Chen and L. Glicksman, System Performance Evaluation and Design Guidelines for Displacement Ventilation, ASHRAE, Altanta, Ga, USA, 2003.

[23] F. Bauman and A. Daly, Underfloor Air Distribution (UFAD) Design Guide, ASHRAE, Altanta, Ga, USA, 2003.

[24] R. Cermak and A. Melikov, "Protection of occupants from exhaled infectious agents and floor material emissions in rooms with personalized and underfloor ventilation," HVAC and $R$ Research, vol. 13, no. 1, pp. 23-38, 2007.

[25] Z. Zhang and Q. Chen, "Experimental measurements and numerical simulations of particle transport and distribution in ventilated rooms," Atmospheric Environment, vol. 40, no. 18, pp. 3396-3408, 2006.

[26] B. C. C. Leite and A. Tribess, "Analysis of thermal comfort in an office environment with underfloor air supply in a tropical climate," HVAC and R Research, vol. 12, no. 2, pp. 215-229, 2006.

[27] B. C. C. Leite and A. Tribess, "Individually controlled office environments-Thermal comfort parameters determination," in Proceedings of the Roomvent, Coimbra, Portugal, 2004.

[28] J. Kaczmarczyk, A. Melikov, Z. Bolashikov, L. Nikolaev, and P. O. Fanger, "Human response to five designs of personalized ventilation," HVAC and R Research, vol. 12, no. 2, pp. 367-384, 2006.

[29] A. K. Melikov, "Personalized ventilation," Indoor Air, vol. 14, supplement 7, pp. 157-167, 2004.

[30] A. K. Melikov, "Improving comfort and health by personalized ventilation," in Proceedings of the Roomvent, University of Coimbra, Coimbra, Portugal, 2004.

[31] J. Kaczmarczyk, A. Melikov, and P. Fanger, "Human response to personalized ventilation and mixing ventilation," Indoor Air, vol. 14, no. 8, pp. 17-29, 2004.

[32] J. Pantelic, G. N. Sze To, K. W. Tham, C. Y. H. Chao, and Y. C. M. Khoo, "Personalized ventilation as a control measure for airborne transmissible disease spread," Journal of the Royal Society Interface, vol. 6, Supplement 6, pp. S715-S726, 2009.

[33] F. Stancato and A. Tribess, "Aircraft gasper jet influence on local thermal comfort," in Proceedings of the International Conference on Indoor Air Quality and Climate, Copenhagen, Denmark, Paper ID: 702, 2008.

[34] J. P. Duguid, "The size and the duration of air-carriage of respiratory droplets and droplet-nuclei," International Journal of Hygiene and Environmental Health, vol. 44, pp. 471-479, 1946.

[35] R. S. Papineni and F. S. Rosenthal, "The size distribution of droplets in the exhaled breath of healthy human subjects," Journal of Aerosol Medicine, vol. 10, no. 2, pp. 105-116, 1997.

[36] D. Bémer, S. Callé, S. Godinot, R. Régnier, and J. M. Dessagne, "Measurement of the emission rate of an aerosol source," Applied Occupational and Environmental Hygiene, vol. 15, no. 12, pp. 904-910, 2000.

[37] J. W. Tang, Y. Li, I. Eames, P. K. S. Chan, and G. L. Ridgway, "Factors involved in the aerosol transmission of infection and control of ventilation in healthcare premises," Journal of Hospital Infection, vol. 64, no. 2, pp. 100-114, 2006.

[38] C. Y. H. Chao, M. P. Wan, L. Morawska et al., "Characterization of expiration air jets and droplet size distributions immediately at the mouth opening," Journal of Aerosol Science, vol. 40, no. 2, pp. 122-133, 2009.

[39] P. Fabian, J. J. McDevitt, W. H. DeHaan et al., "Influenza virus in human exhaled breath: an observational study," PLOS ONE, vol. 3, no. 7, Article ID e2691, 2008. 
[40] C. I. Fairchild and J. F. Stampfer, "Particle concentration in exhaled breath," American Industrial Hygiene Association Journal, vol. 48, no. 11, pp. 948-949, 1987.

[41] M. P. Wan, C. Y. H. Chao, and L. Fang, "Transmission characteristics of passenger-exhaled droplets in a simulated air-cabin environment," in Proceedings of the International Conference on Indoor Air Quality and Climate, 2005.

[42] Z. Zhang, X. Chen, S. Mazumdar, T. Zhang, and Q. Chen, "Experimental and numerical investigation of airflow and contaminant transport in an airliner cabin mock-up," Building and Environment, vol. 44, no. 1, pp. 85-94, 2009.

[43] M. Shimada, K. Okuyama, S. Okazaki, T. Asai, M. Matsukura, and Y. Ishizu, "Numerical simulation and experiment on the transport of fine particles in a ventilated room," Aerosol Science and Technology, vol. 25, no. 3, pp. 242-255, 1996.

[44] J. K. Gupta, C. H. Lin, and Q. Chen, "Transport of expiratory droplets in an aircraft cabin," Indoor Air, vol. 21, no. 1, pp. 3$11,2011$.

[45] Z. Zhang, W. Zhang, Z. J. Zhai, and Q. Chen, "Evaluation of various turbulence models in predicting airflow and turbulence in enclosed environments by CFD. Part-2: comparison with experimental data from literature," HVAC and R Research, vol. 13, no. 6, pp. 853-870, 2007.

[46] Z. Zhai, Z. Zhang, W. Zhang, and Q. Chen, "Evaluation of various turbulence models in predicting airflow and turbulence in enclosed environments by CFD. Part 1: summary of prevalent turbulence models," HVAC and R Research, vol. 13, no. 6, pp. 871-886, 2007.

[47] S. Zhu, S. Kato, and J. Yang, "Study on transport characteristics of saliva droplets produced by coughing in a calm indoor environment," Building and Environment, vol. 41, no. 12, pp. 1691-1702, 2006.

[48] M. P. Wan, C. Y. H. Chao, Y. D. Ng, G. N. Sze To, and W. C. Yu, "Dispersion of expiratory droplets in a general hospital ward with ceiling mixing type mechanical ventilation system," Aerosol Science and Technology, vol. 41, no. 3, pp. 244-258, 2007.

[49] S. B. Poussou, S. Mazumdar, M. W. Plesniak, P. E. Sojka, and Q. Chen, "Flow and contaminant transport in an airliner cabin induced by a moving body: model experiments and CFD predictions," Atmospheric Environment, vol. 44, no. 24, pp. 2830-2839, 2010.

[50] M. P. Wan, G. N. Sze To, C. Y. H. Chao, L. Fang, and A. Melikov, "Modeling the fate of expiratory aerosols and the associated infection risk in aircraft cabin environment," Aerosol Science and Technology, vol. 43, no. 4, pp. 322-343, 2009.

[51] E. Bjørn and P. V. Nielsen, "Dispersal of exhaled air and personal exposure in displacement ventilated rooms," Indoor Air, vol. 12, no. 3, pp. 147-164, 2002.

[52] H. Brohus, K. D. Balling, and D. Jeppesen, "Influence of movements on contaminant transport in an operating room," Indoor Air, vol. 16, no. 5, pp. 356-372, 2006.

[53] E. U. Finlayson, A. J. Gadgil, T. L. Thatcher, and R. G. Sextro, "Pollutant dispersion in a large indoor space. Part 2: computational fluid dynamics predictions and comparison with a scale model experiment for isothermal flow," Indoor Air, vol. 14, no. 4, pp. 272-283, 2004.

[54] Srebric, "An example of verification, validation, and reporting of indoor environment CFD analyses," ASHRAE Transactions, vol. 108, no. 2, pp. 185-194, 2002.

[55] B. Halvoňová and A. K. Melikov, "Performance of "ductless" personalized ventilation in conjunction with displacement ventilation: impact of disturbances due to walking person(s)," Building and Environment, vol. 45, no. 2, pp. 427-436, 2010.

[56] G. N. Sze To, M. P. Wan, C. Y. H. Chao, F. Wei, S. C. T. Yu, and J. K. C. Kwan, "A methodology for estimating airborne virus exposures in indoor environments using the spatial distribution of expiratory aerosols and virus viability characteristics," Indoor Air, vol. 18, no. 5, pp. 425-438, 2008.

[57] A. K. Melikov, "Breathing thermal manikins for indoor environment assessment: important characteristics and requirements," European Journal of Applied Physiology, vol. 92, no. 6, pp. 710-713, 2004.

[58] T. Thatcher, A. C. K. Lai, R. M. Jackson, R. G. Sextro, and W. W. Nazaroff, "Effects of room furnishings and air speed on particle deposition rates indoors," Atmospheric Environment, vol. 36, no. 11, pp. 1811-1819, 2002.

[59] M. L. Pereira, G. Graudenz, A. Tribess, and L. Morawska, "Determination of particle concentration in the breathing zone for four different types of office ventilation systems," Building and Environment, vol. 44, no. 5, pp. 904-911, 2009.

[60] W. C. Hinds, Aerosol Technology, John Wiley Sons, New York, NY, USA, 1999.

[61] N. F. Robinson and D. Lamb, "Technical note: on the calibration of an optical particle counter," Aerosol Science and Techno$\log y$, vol. 5, no. 1, pp. 113-116, 1986.

[62] D. Zukowska, Z. Popiolek, and A. K. Melikov, "Impact of personal factors and furniture arrangement on the thermal plume above a human body," in Proceedings of the 10th International Con-ference on Air Distribution in Rooms-Roomvent, pp. 137-144, Technical University of Denmark, Helsinki, Finland, 2007, paper 1017.

[63] D. Zukowska, A. K. Melikov, and Z. Popiolek, "Thermal plume above a simulated sitting person with different complexity of body geometry," in Proceedings of the 10th International Conference on Air Distribution in Rooms-Roomvent, pp. 191198, Technical University of Denmark, Helsinki, Finland, 2007.

[64] F. Stancato, Aircraft Cabine Thermal Environment Analysis, Doctorate thesis, Polytechnic School of the University of São Paulo, São Paulo, Brazil, 2009.

[65] L. Morawska, "Droplet fate in indoor environments, or can we prevent the spread of infection?" in Proceedings of the International Conference on Indoor Air Quality and Climate, Beijing, China, 2005.

[66] A. K. Melikov, R. Cermak, O. Kovar, and L. Forejt, "Impact of airflow interaction on inhaled air quality and transport of contaminants in rooms with personalized and total volume ventilation," in Proceedings of Healthy Buildings, vol. 2, pp. 592-597, Natiol University of Singapore, Department of Building, Singapore, 2003. 

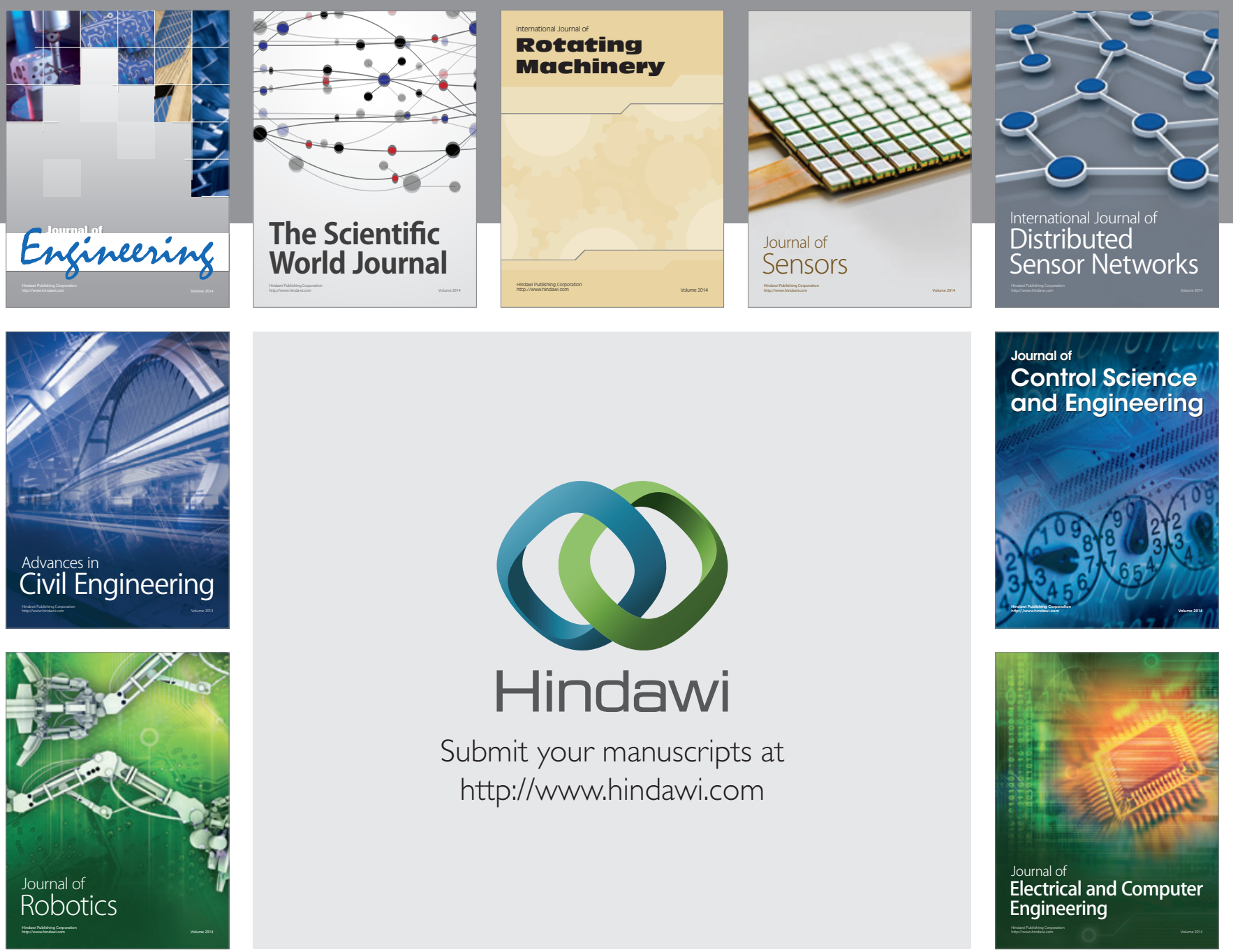

Submit your manuscripts at

http://www.hindawi.com
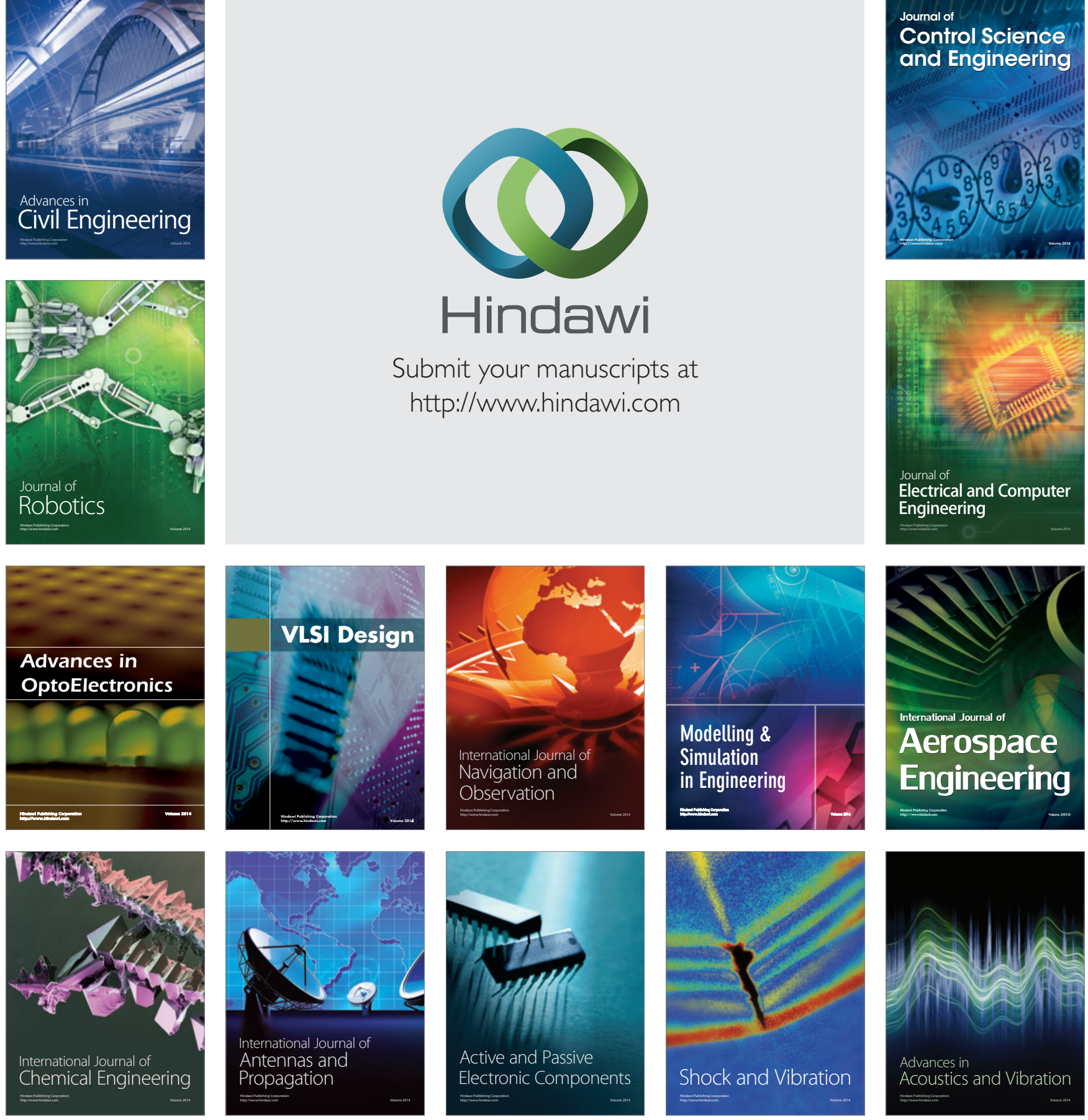